\title{
СОЦІАЛЬНО-ДЕМОГРАФІЧНІ ОСОБЛИВОСТІ ХВОРИХ З ПЕРВИННИМ ЕПІЗОДОМ БІПОЛЯРНОГО АФЕКТИВНОГО РОЗЛАДУ З УРАХУВАННЯМ ГЕНДЕРНОГО ФАКТОРА
}

\section{ФЮ. І. Мисула}

Тернопільський національний медичний університет імені І. Я. Горбачевського МОз України

РЕЗЮМЕ. Проблема біполярного афективного розладу (БАР) $є$ однією з найактуальніших проблем сучасної психіатрії.

Мета - вивчити соціально-демографічні особливості хворих на БАР на момент первинного епізоду і впродовж життя з урахуванням гендерного фактора.

Матеріал і методи. Проаналізовано особливості перебігу первинного епізоду БАР на підставі медичної документації 180 чоловіків і 222 жінок із встановленим діагнозом БАР.

Результати. Встановлено переважання осіб з неповною середньою (загалом 24,7 \%, чоловіків 28,4 \%, жінок $21,6 \%$, p>0,05), середньою (відповідно 21,6 \%, 27,9 \% і 13,9 \%, p<0,01), та середньою спеціальною освітою (20,4 \%, $22,2 \%$ і 18,9 \%, p>0,05), меншою є питома вага осі6 з незакінченою вищою $(20,4 \%, 18,3$ \% і $22,1 \%$, p>0,05), професійно-технічною $(7,2 \% ; 11,1 \%$ і 4,1 \%, p<0,01) і вищою освітою $(5,7 \%, 6,1 \%$ і 5,4 \%, p>0,05). Більшість хворих були безробітними (40,0 \%, 37,8 \%, 41,9\%, p>0,05), менше - школярів $(24,7 \%, 28,3$ \% та 21,6 \%, р>0,05), студентів $(11,7 \%, 12,8 \%$ і 10,8 \%, p>0,05), робітників $(8,7 \%, 10,6 \%$ і 7,2 \%, p>0,05), службовців $(8,2 \%, 6,1 \%$ і $9,9 \%, p>0,05)$, підприємців $(4,0 \%, 3,3$ \% і 4,5\%, p>0,05) та пенсіонерів $(2,7 \%, 1,1 \%$ і 4,1 \%, p>0,05). Більшість хворих не були одруженими $(60,7 \%, 66,7$ \% і 55,9 \%, p>0,05), менше було одружених (35,9 \%, 28,3 \% і 41,9 \%, p>0,05), розлучених $(2,7 \%, 3,9 \%$ i $1,8 \%, p>0,05)$ та вдових $(0,7 \%, 1,1 \%$ і 0,4 \%, p>0,05); а також бездітних $(78,9 \%, 79,4 \%$ i $78,4 \%, p>0,05)$ і тих, що проживали з батьками (59,5\%, 65,6 \% і 54,5\%, p<0,05). Чоловіки частіше були курцями (58,3 \% проти $24,8 \%$, p $<0,01$, разом 39,7 \%), з епізодичним та частим вживанням алкоголю (відповідно 53,3 \% і 33,8 \%, p<0,01, разом $42,5 \%$, та $21,1 \%$ і $1,8 \%$, p $<0,01$, разом $10,5 \%)$.

Висновки. Хворим з первинним епізодом БАР притаманні невисокий освітній та професійний рівень, погана сімейна реалізація, поширеність куріння; для чоловіків характерні нижчий рівень освіти з більшою професійною спрямованістю, вищий рівень інвалідизації, гірша сімейна реалізація, а також більший рівень ураження аддикціями. Ці дані можуть бути використані для ранньої діагностики та профілактики БАР.

КлючОВІ СлОВА: біполярний афективний розлад; первинний епізод; соціально-демографічні особливості.

Вступ. Проблема біполярного афективного розладу (БАР) $\epsilon$ однією з найактуальніших проблем сучасної психіатрії: БАР уражено від 0,6 \% до 1,0 \% популяції, і захворюваність на цей розлад залишається відносно стабільною впродовж тривалого часу [1-3]. БАР $\epsilon$ патологією, яка призводить до значущих медико-соціальних наслідків, адже проявляється у молодому віці і супроводжується вираженими медичними та соціальними наслідками: хронічним перебігом, високим ступенем соціальної дезадаптації, значною втратою працездатності та якості життя, коморбідною залежністю від психоактивних речовин, надзвичайно високим суїцидальним ризиком, зниженням тривалості життя в середньому на 10 років і потребою в тривалій терапії, а також високою інвалідизацією $[4,5]$. Аналіз первинного епізоду має надзвичайно велике значення для прогнозування й довгострокового планування при БАР [6]. При цьому діагностика БАР на ініціальному етапі захворювання $\epsilon$ недостатньою внаслідок поліморфізму категорії біполярності, високого рівня коморбідності та недосконалості діагностичних підходів [7]. Від першого епізоду БАР до встановлення вірного діагнозу в значній частині випадків минає 5-10 років [8-10]. Усе це зумовлює актуальність дослідження різних аспектів первинного епізоду БАР, що $\epsilon$ підґрунтям для розробки методів ранньої діагностики та профілактики цього розладу.

Мета - вивчення соціально-демографічних особливостей хворих на БАР на момент первинного епізоду і впродовж життя з урахуванням гендерного фактора.

Матеріал і методи дослідження. Ми проаналізували особливості перебігу первинного епізоду захворювання у пацієнтів із встановленим діагнозом БАР на підставі медичної документації (історій хвороби, амбулаторних карт, епікризів, виписок, консультаційних висновків, інших медичних документів). Усього було проаналізовано 402 випадки захворювань на БАР: 180 чоловіків (44,8 \%) та 222 жінки (55,2 \%). Середній вік хворих на момент даного дослідження склав $(36,8 \pm 9,8)$ років (чоловіків - $(37,1 \pm 10,0)$ років, жінок - $(36,6 \pm 9,6)$ років), середня тривалість захворювання на БАР $(12,7 \pm 5,3)$ років (у чоловіків - $(12,8 \pm 5,6)$ років, у жінок - $(12,6 \pm 5,1)$ років). Мінімальний вік пацієнтів на момент дослідження склав 20 років (чоловіків 21 рік, жінок - 20 років), максимальний - 67 років 
Огляди літератури, оригінальні дослідження, погляд на проблему, випадок з практики, короткі повідомлення (чоловіків - 66 років, жінок - 67 років). Інтерквартильний діапазон за віком склав 30,0-42,0 років (чоловіків - 29,0-43,0 років, жінок - 30,0-40,0 років), за тривалістю захворювання - 8,0-16,0 років (для чоловіків - 8,0-17,0 років, для жінок - 9,016,0 років). 206 осіб (51,2 \%) з числа обстежених проживали у містах, 196 осіб (48,8 \%) - у сільській місцевості. Серед чоловіків 89 осіб (49,4 \%) були мешканцями міст, 91 особа (50,6 \%) - мешканцями сільської місцевості, серед жінок 117 осіб (52,7 \%) були мешканками міст, 105 осіб (47,3 \%) - мешканцями сільської місцевості.

Середній вік на момент первинного епізоду захворювання на БАР у обстежених хворих склав $(24,2 \pm 10,9)$ років (чоловіків $(23,7 \pm 10,8)$ років, жінок $(24,5 \pm 11,0)$ років, p>0,05). Середній вік першого звернення за медичною допомогою склав $(24,3 \pm 11,1)$ років (чоловіків $(23,8 \pm 11,0)$ років, жінок $(24,7 \pm 11,2)$ років, р>0,05). Статистичну обробку отриманих даних проводили з використанням точного критерію Фішера.

Результати й обговорення. При аналізі освітнього рівня на момент виникнення захворювання на БАР виявлено, що більшість хворих не мали повної середньої освіти: загалом 24,7 \% (28,4 \% чоловіків, 21,6 \% жінок, розбіжності між чоловіками та жінками статистично не значущі, p>0,05). Дещо меншою є питома вага обстежених з середньою освітою (21,6 \%), при цьому жінок з середньою освітою значуще більше, ніж чоловіків (27,9 \% проти 13,9 \%, p<0,01). Близькою є питома вага обстежених з середньою спеціальною освітою (загалом 20,4 \%, 22,2 \% чоловіків і 18,9 \% жінок, р>0,05) та незакінченою вищою освітою (загалом 20,4 \%, 18,3 \% чоловіків і 22,1 \% жінок, p>0,05). Суттєво меншоює питома вага осіб з професійно-технічною освітою (в цілому 7,2 \%; чоловіків значуще більше, ніж жінок: 11,1 \% проти 4,1 \%, p<0,01). Найменшою була питома вага осіб з повною вищою освітою (загалом 5,7 \%, 6,1 \% чоловіків і 5,4 \% жінок, p>0,05).

В подальшому освітній рівень хворих на БАР зростає не суттєво. Певна частина хворих вступає до вищих навчальних закладів, але завершити навчання не в змозі (загалом 25,4 \%, чоловіки $25,0 \%$, жінки 25,7\%, p>0,05). Більшість обстежених на момент проведення дослідження мали середню освіту (загалом 29,4 \%, 31,1 \% чоловіків, 27,9 \% жінок, р>0,05), а 1,7 \% (2,2\% чоловіків, 1,4 \% жінок) - неповну середню; при цьому середній вік обстежених склав $(36,8 \pm 9,8)$ років. Дещо зменшується питома вага чоловіків з професійно-технічною освітою (за рахунок здобуття освіти більш високого рівня) - 9,4 \%, і збільшується - жінок (6,3 \%), p>0,05 (загалом 7,7 \%). Незначно зменшується питома вага чоловіків з середньою спеці-

альною освітою (до 20,6 \%), і збільшується - жінок (до 26,1%), р>0,05. При цьому лише 12,2 \% хворих вдається здобути повну вищу освіту (11,7 \% чоловіків, 12,6\% жінок, р>0,05).

На момент первинного епізоду БАР переважна більшість хворих були безробітними (40,0 \% загалом, 37,8 \% чоловіків, 41,9 \% жінок, р>0,05), значною також була питома вага школярів (відповідно 24,7 \%, 28,3 \% та 21,6 \%, р>0,05); суттєво меншою - студентів (відповідно 11,7 \%, 12,8 \% та 10,8 \%, р>0,05), робітників (відповідно 8,7 \%, 10,6\% та 7,2 \%, р>0,05), службовців (відповідно 8,2 \%, 6,1\% та 9,9\%, р>0,05) та підприємців (відповідно 4,0 \%, 3,3 \% та 4,5\%, р>0,05), і вельми незначною пенсіонерів (відповідно 2,7 \%, 1,1 \% та 4,1\%, $p>0,05)$.

В подальшому соціальний статус хворих на БАР відображає особливості перебігу захворювання. Переважну їх більшість складають безробітні (68,4 \% разом, 66,1 \% чоловіки, 70,3 \% жінки, p>0,05), значно меншою $є$ питома вага службовців (відповідно 10,7 \%, 8,9 \% та 12,2 \%, р>0,05), робітників (відповідно 4,7 \%, 6,7 \% та 3,0 \%, р>0,05), підприємців (відповідно 4,5 \%, 4,4 \% та 4,5\%, p $>0,05$ ) та пенсіонерів за віком (відповідно 3,5 \%, $2,8 \%$ та 4,1 \%, р>0,05). Інвалідність встановлена у 8,2 \% хворих (11,1 \% чоловіків та 5,9 \% жінок, p<0,05), у тому числі II групи - відповідно у 2,0\%, $2,8 \%$ та 1,4\% (p>0,05), III групи - у 6,2 \%, 8,3 \% та $4,5 \%(p>0,05)$.

При аналізі трудового анамнезу на час обстеження було виявлено, що працювали протягом життя (хоча 6 тимчасово) 77,1 \% хворих (75,6 \% чоловіків та 78,4 \% жінок, р>0,05). На час обстеження працювали лише 19,7 \% хворих (20,0% чоловіків і 19,4 \% жінок, p>0,05), у тому числі за спеціальністю 9,5 \% хворих (8,3 \% чоловіків та 10,4 \% жінок, р>0,05), не за спеціальністю - 10,2 \% (11,7 \% чоловіків та 9,0\% жінок, р>0,05).

На час виникнення захворювання більшість хворих не були одруженими $(60,7$ \% загалом, $66,7 \%$ чоловіків, 55,9 \% жінок, р>0,05). Одружених було відповідно 35,9 \%, 28,3 \% та 41,9 \% (p>0,05), розлучених - відповідно 2,7 \%, 3,9 \% та 1,8 \% ( $>0,05)$, вдових - відповідно 0,7 \%, 1,1\% та 0,4 \% ( $>0,05)$. На час обстеження також найбільшою була питома вага неодружених (44,5 \% загалом, чоловіків значуще більше, ніж жінок - відповідно 52,2 \% проти 38,2 \%, p<0,01). Значною $\epsilon$ також питома вага розлучених (відповідно 27,9 \%, 25,0 \% та $30,2 \%$, р>0,05), одружені на час обстеження 26,4 \% хворих (21,7 \% чоловіків, 30,2 \% жінок, р<0,05). 5 хворих $(1,2 \%)$ на час обстеження були вдовими (1,1\% чоловіків і 1,3\% жінок, p>0,05).

Більшість хворих на БАР на час виникнення захворювання були бездітними (загалом 78,9%, 
Огляди літератури, оригінальні дослідження, погляд на проблему, випадок з практики, короткі повідомлення чоловіків 79,4\%, жінок 78,4 \%), у 13,9 \% було по одній дитині (12,8 \% чоловіків, 14,9\% жінок), у 5,0 \% по двоє дітей (6,1 \% чоловіків, 4,1\% жінок), у 2,2 \% - троє і більше дітей (1,7 \% чоловіків, 2,6 \% жінок). На час обстеження більшість хворих також залишалися бездітними (65,7 \% загалом, 68,9 \% чоловіків та $63,1 \%$ жінок). У 23,9 \% хворих $\epsilon$ одна дитина (23,3 \% чоловіків, 24,3 \% жінок), у 8,2 \% двоє дітей (6,1 \% чоловіків, 9,9 \% жінок), у 2,2 \% троє і більше дітей (1,7 \% чоловіків, 2,7 \% жінок).

Особливості мікросоціального оточення хворих на БАР також тісно пов'язані з наявністю психічного захворювання. На час первинного епізоду захворювання переважна більшість хворих проживали з батьками (59,5 \% загалом, 65,6 \% чоловіків, 54,5 \% жінок, р<0,05). Одружені на час первинного епізоду зазвичай проживали з подружжям (відповідно 32,6 \%, 23,3 \%, 40,1%, р<0,01). Питома вага самотніх була відносно невеликою: відповідно 5,7 \%, 8,3 \%, 3,5 \% (p<0,05). 3 іншими родичами проживали 0,2 \% хворих (0,5 \% жінок), з іншими особами - 2,0 \% хворих (2,8 \% чоловіків, 1,4 \% жінок).

В подальшому значна частина хворих на БАР залишається самотніми: $27,1 \%$, чоловіки частіше, ніж жінки: 35,7 \% проти 20,3\% (p<0,01). Ще 15,9\% хворих проживають з батьками, чоловіки також частіше, ніж жінки: 23,3 \% проти 9,9\% (p<0,01). Натомість, жінки частіше проживають з подружжям: 24,3 \% проти 13,3 \%, p<0,01 (загалом 19,4 \%). 3 іншими родичами проживають 5,7 \% хворих (4,4 \% чоловіків, 6,8 \% жінок). 3 іншими особами (переважно у цивільному шлюбі) проживають 31,9 \% хворих (23,3 \% чоловіків, 38,7 \% жінок, p<0,01).

При аналізі особливостей аддиктивної поведінки на час первинного епізоду захворювання виявлено, що 39,7 \% хворих курили (58,3 \% чоловіків, 24,8 \% жінок, р<0,01), у тому числі до 10 сигарет на добу 31,3 \% хворих (42,2 \% чоловіків, $22,5 \%$ жінок, $p<0,01)$, від 10 до 20 сигарет на добу - 7,7 \% хворих (14,4 \% чоловіків і 2,3 \% жінок, p<0,01), понад 20 сигарет на добу - 0,7 \% хворих (1,7 \% чоловіків).

Не вживали алкоголь на час первинного епізоду захворювання на БАР 47,0 \% обстежених (25,6 \% чоловіків і 64,4 \% жінок, р<0,01), вживали епізодично 42,5 \% осіб (53,3 \% чоловіків і 33,8 \% жінок, p<0,01), зловживали алкоголем 10,5 \% осіб (21,1 \% чоловіків та 1,8 \% жінок, р<0,01).

3 вищенаведеного можна зробити висновок, що хворим на час виникнення первинного епізоду БАР притаманні певні соціально-демографічні відмінності, які залежать від статі.

В цілому дані нашого дослідження узгоджуються з даними ряду інших науковців, які вказують ранній дебют БАР, відсутність суттєвих гендерних відмінностей у віці початку, а також виражені прояви соціальної дезадаптації хворих на БАР. Однак у нашому дослідженні були виявлені й деталізовані нові дані щодо соціально-демографічних характеристик хворих з первинним епізодом БАР, з урахуванням гендерного фактора, зокрема, щодо особливостей освітнього рівня, професійної реалізації, сімейного стану та мікросоціального оточення.

Результати нашого дослідження можуть бути використані для розробки заходів з раннього виявлення, лікування, реабілітації та профілактики при БАР.

Висновки. 1. Хворим із первинним епізодом БАР притаманні певні соціально-демографічні характеристики, які включають молодий вік, невисокий освітній та професійний рівні, низький ступінь сімейної реалізації та поширення аддиктивної поведінки, насамперед, куріння.

2. Чоловікам з первинним епізодом БАР, порівняно з жінками, притаманні нижчий рівень освіти з її більшою професійною спрямованістю, вищий рівень інвалідизації внаслідок БАР, гірша сімейна реалізація, а також вищий рівень ураження аддикціями.

3. Особливості соціально-демографічних характеристик хворих на БАР необхідно враховувати при розробці діагностичних, лікувальних, реабілітаційних та профілактичних заходів.

Перспективи подальших досліджень полягають у детальному дослідженні соціально-демографічних характеристик осіб з первинним епізодом БАР, з урахуванням різних клінічних варіантів первинного епізоду захворювання, й розробці на підставі результатів цих досліджень комплексних програм ранньої діагностики та профілактики БАР. 
Огляди літератури, оригінальні дослідження, погляд на проблему, випадок з практики, короткі повідомлення ЛІТЕРАТУРA

1. Mental health: strengthening our response / Information Bulletin of World Health Organisation. - Geneva, WHO, 2018. - P. 1-28.

2. Delays before diagnosis and initiation of treatment in patients presenting to mental health services with bipolar disorder / R. Patel, H. Shetty, R. Jackson [et al.] // PLoS One. - 2015. - Vol. 10. - P. 126-129.

3. Cognitive functioning in first episode bipolar I disorder patients with and without history of psychosis / T. Chakrabarty, G. Alamian, J. Kozicky [et al.] // Journal of Affective Disorders. - 2018. - Vol. 227. - P. 109-116.

4. Марута Н. А. Биполярное аффективное расстройство: диагностика, терапия, профилактика / Н. А. Марута // НейрoNews. - 2011. - № 8 (35). - C. 46-52.

5. A systematic review and meta-analysis of premature mortality in bipolar affective disorder / J. F. Hayes, J. Miles, K. Walters [et al.] // Acta. Psychiatrica Scandinavica. - 2015. - Vol. 131. - P. 417-425.

\section{REFERENCES}

1. Mental health: strengthening our response (2018) Information Bulletin of World Health Organisation. Geneva, WHO.

2. Patel, R., Shetty, H., Jackson, R., Broadbent, M., Stewart, R., \& Boydell, J. (2015). Delays before diagnosis and initiation of treatment in patients presenting to mental health services with bipolar disorder. PLoS One. 10, 126-129.

3. Chakrabarty, T., Alamian, G., Kozicky, J.M., Ivan, J.T., \& Lakshmi, N.Y. (2018). Cognitive functioning in first episode bipolar I disorder patients with and without history of psychosis. Journal of Affective Disorders, 227, 109-116.

4. Maruta, N.A. (2011). Bipolarnoye affektivnoye rasstroystvo: diagnostika, terapiya, profilaktika [Bipolar affective disorder: diagnostic, treatment, prophylaxis]. NeuroNews, 8 (35), 46-52 [in Russian].

5. Hayes, J.F., Miles, J., \& Walters, K. (2015). A systematic review and meta-analysis of premature mortality in bipolar affective disorder. Acta Psychiatrica Scandinavica, $131,417-425$.
6. Rowland T. A. Epidemiology and risk factors for bipolar disorder / T. A. Rowland, S. Marwaha // Therapeutic Advances in Psychopharmacology. - 2018. - Vol. 8 (9). - P. 251-269.

7. Марута Н. А. Диагностика биполярного аффективного расстройства / Н. А. Марута // НейроNews. 2011. - № 4 (31). - C. 57-60.

8. Baldessarini R. J. First-episode types in bipolar disorder: predictive associations with later illness / R. J. Baldessarini, L. Tondo, C. Visioli // Acta. Psychiatrica Scandinavica. - 2014. - Vol. 129. - P. 383-392.

9. Clinical risk factors for bipolar disorders: a systematic review of prospective studies / G. L. Faedda, G. Serra, C. Marangoni [et al.] // Journal of Affective Disorders. 2014. - Vol. 168. - P. 314-321.

10. Antecedents of manic versus other first psychotic episodes in 263 bipolar I disorder patients / P. Salvatore, R. J. Baldessarini, H. M. Khalsa [et al.] // Acta. Psychiatrica Scandinavica. - 2014. - Vol. 129. - P. 275-285.

6. Rowland, T.A., \& Marwaha, S. (2018). Epidemiology and risk factors for bipolar disorder. Therapeutic Advances in Psychopharmacology, 8 (9), 251-269.

7. Maruta, N.A. (2011). Diagnostika bipolarnogo affektivnogo rasstroystva [Diagnostic of bipolar affective disorder]. NeuroNews, 4 (31), 57-60 [in Russian].

8. Baldessarini, R.J., Tondo, L., \& Visioli, C. (2014). First-episode types in bipolar disorder: predictive associations with later illness. Acta Psychiatrica Scandinavica, 129, 383-392.

9. Faedda, G.L., Serra, G., \& Marangoni, C. (2014). Clinical risk factors for bipolar disorders: a systematic review of prospective studies. Journal of Affective Disorders, 168, 314-321.

10. Salvatore, P., Baldessarini, R.J., \& Khalsa, H.M. (2014). Antecedents of manic versus other first psychotic episodes in 263 bipolar I disorder patients. Acta Psychiatrica Scandinavica, 129, 275-285.

\title{
СОЦИАЛЬНО-ДЕМОГРАФИЧЕСКИЕ ОСОБЕННОСТИ БОЛЬНЫХ С ПЕРВИЧНЫМ ЭПИЗОДОМ БИПОЛЯРНОГО АФФЕКТИВНОГО РАССТРОЙСТВА С УЧЕТОМ ГЕНДЕРНОГО ФAKTOPA
}

○Ю. И. Мисула

\author{
Тернопольский национальный медицинский университет имени И. Я. Горбачевского Мз Украины
}

РЕЗЮМЕ. Проблема биполярного аффективного расстройства является одной из наиболее актуальных проблем современной психиатрии.

Цель исследования - изучить социально-демографические особенности больных БАР на момент первичного эпизода и в течение жизни с учетом гендерного фактора.

Материал и методы. Проанализированы особенности течения первичного эпизода БАР на основании медицинской документации 180 мужчин и 222 женщин с установленным диагнозом БАР.

Результаты. Установлено преобладание лиц с неполным средним (всего 24,7 \%, мужчин 28,4 \%, женщин $21,6 \%$, p>0,05), средним (соответственно 21,6 \%, 27,9 \% и 13,9\%, p<0,01), и средним специальным образованием $(20,4 \%, 22,2$ \% и 18,9 \%, p>0,05), меньшим оказался удельный вес лиц с незаконченным высшим (20,4 \%, 18,3 \% и 
Огляди літератури, оригінальні дослідження, погляд на проблему, випадок з практики, короткі повідомлення $22,1 \%, p>0,05)$, профессионально-техническим $(7,2 \% ; 11,1 \%$ и 4,1\%, p<0,01) и высшим образованием $(5,7 \%, 6,1 \%$ и 5,4 \%, р>0,05). Большинство больных были безработными $(40,0 \%, 37,8 \%, 41,9 \%, p>0,05)$, меньше было школьников $(24,7 \%, 28,3 \%$ и $216 \%$, р>0,05), студентов $(11,7 \%, 12,8 \%$ и 10,8 \%, p>0,05), ра6очих (8,7 \%, 10,6 \% и $7,2 \%, p>0,05)$, служащих (8,2 \%, 6,1 \% и 9,9\%, p<0,05), предпринимателей $(4,0 \%, 3,3 \%$ и 4,5\%, p>0,05) и пенсионеров $(2,7 \%, 1,1 \%$ и 4,1 \%, p>0,05). Большинство больных не состояли в браке $(60,7 \%, 66,7 \%$ и 55,9 \%, p>0,05), меньше было женатых (35,9\%, 28,3 \% и 41,9\% p>0,05), разведенных $(2,7 \%, 3,9 \%$ и 1,8 \%, p>0,05) и вдовых $(0,7 \%, 1,1 \%$ и 0,4 \%, p>0,05); были бездетными (78,9 \%, 79,4 \% и 78,4 \%, p<0,05) и проживали с родителями $(59,5 \%, 65,6 \%$ и $54,5 \%, p<0,05)$. Среди мужчин значительно больше распространено курение (58,3 \% против 24,8 \%, p<0,01, всего $39,7 \%)$, эпизодическое и частое употребление алкоголя (соответственно 53,3 \% против 33,8 \%, p<0,01, всего $42,5 \%$ и и 21,1 \% и 1,8 \%, р<0,01, всего 10,5\%).

Выводы. Больным с первичным эпизодом БАР присущи низкий образовательный и профессиональный уровень, плохая семейная реализация, распространенность курения; для мужчин характерны низкий уровень образования с большей профессиональной направленностью, высокий уровень инвалидизации, худшая семейная реализация, а также больший уровень распространенности аддикций. Эти данные могут быть использованы для ранней диагностики и профилактики БАР.

КЛЮЧЕВЫЕ СЛОВА: биполярное аффективное расстройство; первичный эпизод; социально-демографические особенности.

\section{SOCIO-DEMOGRAPHIC FEATURES OF PATIENTS WITH THE PRIMARY EPISODE OF BIPOLAR AFFECTIVE DISORDER WITH CONSIDERATION OF THE GENDENER FACTOR}

○Y. I. Mysula

\section{Horbachevsky Ternopil National Medical University}

SUMMARY. Problem of bipolar affective disorder is one of the actual problems in modern psychiatry.

The aim of the study - to investigate socio-demographic characteristics of patients with bipolar affective disorder (BAD) at the time of the initial episode and during the life based on the gender factor.

Material and Methods. We studied the medical records of 180 men and 222 women with initial BAD episode.

Results and Discussion. The prevalence among patients with incomplete secondary education was found (in general, $24.7 \%$, men $28.4 \%$, women $21.6 \%$, p>0.05), secondary education $(21.6 \%, 27.9 \%$ and 13 respectively, $9 \%$, $\mathrm{p}<0.01)$, and the average special education $(20.4 \%, 22.2 \%$ and $18.9 \%, p>0.05)$, the share of persons with unfinished higher is lower $(20.4 \%, 18.3 \%$ and $22.1 \%, p>0.05)$, vocational-technical $(7.2 \%, 11.1 \%$ and $4.1 \%, p<0.01)$ and higher education $(5,7 \%, 6.1 \%$ and $5.4 \%, p>0.05)$. The majority of patients were unemployed $(40.0 \%, 37.8 \%, 41.9 \%, p>0.05)$, the proportion of students was significant $(24.7 \%, 28.3 \%$ and $21,6 \%, p>0.05)$, less - students $(11.7 \%, 12.8 \%$ and $10.8 \%, p>0.05)$, workers ( $8.7 \%, 10.6 \%$, and $7,2 \%, p>0.05)$, employees $(8.2 \%, 6.1 \%$ and $9.9 \%, p>0.05)$, and entrepreneurs (4.0\%, $3.3 \%$ and $4.5 \%, p>0.05)$, pensioners $(2.7 \%, 1.1 \%$ and $4.1 \%, p>0.05)$. The majority of patients were not married $(60.7 \%, 66.7 \%$ and $55.9 \%, p>0.05)$, less were married (35.9 \%, $28.3 \%$, and $41.9 \%, p>0.05)$, divorced $(2.7 \%$, $3.9 \%$ and $1.8 \%, p>0.05)$, widows $(0.7 \%, 1.1 \%$ and $0.4 \%, p>0.05)$. The majority of patients were childless $(78.9 \%, 79.4 \%$ and $78.4 \%, \mathrm{p}>0.05)$ and lived with their parents $(59.5 \%, 65.6 \%$ and $54.5 \%, \mathrm{p}<0.05)$. Among males, tobacco infection is much higher (58.3\% vs $24.8 \%$, p<0.01, total $39.7 \%$ ), episodic and frequent use of alcohol ( $53.3 \%$ vs $33,8 \%$, $p<0.01$, total $42.5 \%$, and $21.1 \%$ vs $1.8 \%$, $p<0.01$, total $10.5 \%)$.

Conclusions. Patients with an initial episode of BAD have low educational and professional level, low degree of family implementation and prevalence of tobacco smoking; while men are characterized by a lower level of education with more professional orientation, higher levels of disability, a worse implementation of the family, and more severity of addictions. These data can be used for early diagnosis and prevention of BAD.

KEY WORDS: bipolar affective disorder; primary episode; socio-demographic features. 